\title{
Ingestive behavior of heifers on Brachiaria pasture deferred with different periods of sealing
}

\section{Comportamento ingestivo de novilhas em pastos de Braquiaria diferidos com diferentes períodos de vedação}

\author{
José Dionísio Borges de Macêdo ${ }^{1}$; Fábio Andrade Teixeira ${ }^{2}$; \\ Fabiano Ferreira da Silva ${ }^{2}$; Aureliano José Vieira Pires ${ }^{2}$; \\ Poliana Batista de Aguilar ${ }^{*}$; Paulo Valter Nunes Nascimento ${ }^{2}$
}

\begin{abstract}
This study aimed to evaluate four deferral periods for pastures of Brachiaria decumbens $\mathrm{cv}$. Basilisk, and the implications on the ingestive behavior of crossbred heifers. Animals were distributed in a completely randomized design with four periods $(63,84,105$ and 126 days), each with three replications. The time spent daily by animals on grazing, idle, rumination and in the trough was not affected by periods of sealing the pastures, with mean values of $566.6 ; 422.29 ; 426.9$ and 24.1 minutes, respectively. The number of feeding stations, the time spent in the stations and the number of feeding stations per minute were not different between periods of sealing the pastures, averaging 106.4; 34.6 and 3.0, respectively. The number of bites and the number of bites per minute showed a quadratic effect, with a point of maximum equal to 1,098 bites and 31 bites per minute, observed on days 93 and 88, respectively. Feed efficiency was linearly decreasing influenced by periods of sealing the pastures. Periods of grazing and idle, the number of bites, the number of bites per minute and feed efficiency are influenced by different deferral periods of pastures under the conditions of this study.
\end{abstract}

Key words: Deferral. Idleness. Grazing. Ruminating. Supplementation.

\section{Resumo}

Objetivou-se com este estudo avaliar períodos de diferimento para pastos de Brachiaria decumbens cv. Basilisk, e suas implicações sobre o comportamento ingestivo de novilhas. As novilhas foram distribuídas em delineamento inteiramente casualizado, com quatro períodos (63, 84, 105 e 126 dias), cada um com três repetições. Os tempos gastos diariamente pelos animais em pastejo, ócio, ruminação e no cocho não foram influenciados pelos períodos de vedação dos pastos, com valores médios de 566,6; 422,3; 426,9 e 24,1 minutos, respectivamente. O número de estações alimentares, o tempo nas estações e o número de estações alimentares por minuto não diferiram entre os períodos de vedação dos pastos, com médias de 106,4; 34,6 e 3,0, respectivamente. O número de bocados e o número de bocados por minuto apresentou efeito quadrático, com ponto de máxima igual a 1.098 bocados e 31 bocados por minuto, alcançados aos 93 e 88 dias, respectivamente. A eficiência alimentar foi influenciada de forma linear decrescente pelos períodos de vedação. Os períodos de pastejo e de ócio, o número de bocados e número de bocados por minuto e a eficiência alimentar são influenciados pelos diferentes períodos de diferimento dos pastos, nas condições de realização desta pesquisa.

Palavras-chave: Diferimento. Ócio. Pastejo. Ruminação. Suplementação.

\footnotetext{
${ }^{1}$ Drs. em Zootecnia, Departamento de Zootecnia, Universidade Estadual do Sudoeste da Bahia, UESB, Itapetinga, BA, Brasil. E-mail: macedojdb@yahoo.com.br; poliana.aguilar@bol.com.br

${ }^{2}$ Profs. Drs., Departamento de Zootecnia, UESB, Itapetinga, BA, Brasil. E-mail: fteixeira@uesb.edu.br; ffsilvauesb@hotmail. com; aurelianojvp@yahoo.com.br; pvalter@uesb.edu.br

* Author for correspondence
} 


\section{Introduction}

Livestock production on pastures is the most used in Brazil, mainly due to the territorial extension of the country and is the simplest form of management with the lowest cost available. In this way, pastures are essential in Brazilian cattle production, which has a herd of about 199 million animals (ANUALPEC, 2013). Despite the advantages of the production on pasture, climate seasonality, with rainy and dry seasons, also results in seasonal production with high dry matter production in the rainy season and low production during the dry season. Consequently, extensive cattle ranching results in seasonality in animal production.

Alternatives able to solve or reduce the effects of production seasonality that also permit to increase the stocking rate of pastures, with maintenance and even weight gain in the dry season, are extremely important to the national livestock production. Thus, deferral of pastures, which consists of sealing pasture areas at the end of the rainy season for use during the dry season, is an alternative to balance this seasonality in forage production and, consequently, in animal production. This strategy has proven to be a viable solution, because it has low cost and can be easily adopted.

Cattle production on pasture is characterized by a number of factors whose interactions can affect feeding behavior of animals, interfering with various factors and performance. According to Palhano et al. (2007), the daily forage intake is central to greater understanding of the behavior of grazing animals, directly influenced by factors related to the forage plant and the animal. Animals tend to be more selective, grazing a pasture with a lower leaf: stem ratio and a lower availability of forage (ZANINE et al., 2006b).

The objective of this study was to evaluate deferral periods for pastures of Brachiaria decumbens cv. Basilisk, and the implications on the feeding behavior of heifers.

\section{Material and Methods}

The experiment was conducted at the Federal Institute Bahian - Campus Itapetinga, at 15'14'54" South latitude, $40^{\circ} 14^{\prime} 16^{\prime \prime}$ West longitude, in the municipality of Itapetinga, southwest region of Bahia, from March $23^{\text {rd }}$ to October $6^{\text {th }}, 2012$. Analyses of the samples were carried out in the Forage and Pasture Laboratory of the State University of Southwest Bahia - Campus Itapetinga. The climate is $\mathrm{Cw}$, humid and sub-humid mesothermal, hot and with dry winter, according to Köppen classification. The rainy season is hot and covers the months from October to April and the dry season is cold, no rainfall and extends from May to October. In the experimental area, using thermometer and rain gauge, were obtained weather data on temperature and rainfall in the period from March to October 2012 (Table 1).

Table 1. Monthly averages of the mean, maximum and minimum temperature $\left({ }^{\circ} \mathrm{C}\right)$ and rainfall (mm) during the study period.

\begin{tabular}{|c|c|c|c|c|c|c|c|c|}
\hline & Mar & Apr & May & Jun & Jul & Aug & Sep & Oct \\
\hline & \multicolumn{4}{|c|}{ Deferral period } & \multicolumn{4}{|c|}{ Utilization period } \\
\hline Mean temperature & 26.5 & 27.3 & 23.8 & 24.5 & 23.2 & 24.0 & 25.5 & 25.6 \\
\hline Maximum temperature & 34.0 & 35.0 & 33.0 & 33.0 & 30.0 & 33.5 & 32.5 & 32.5 \\
\hline Minimum temperature & 16.8 & 19.0 & 19.0 & 18.0 & 15.0 & 16.0 & 16.0 & 19.0 \\
\hline Rainfall index & 63.4 & 0.00 & 62.26 & 35.4 & 35.0 & 46.0 & 13.0 & 35.2 \\
\hline
\end{tabular}

Source: Elaboration of the authors. 
The soil of the experimental area is classified as Chernossolo with sandy clay loam texture and its chemical characteristics are listed in Table 2. No additional fertilization was applied in the study area, in order to characterize the management adopted by most producers in the municipality.

The experiment was established in a homogeneous area, flat, well-formed and planted with Brachiaria decumbens cv. Basilisk. This was a completely randomized design, with four deferral periods (63, 84, 105 and 126 days), each with three replications, totaling 12 experimental units, represented by paddocks. The experimental units had differentiated areas ( 0.76 ha in paddocks deferred for 63 days, 0.57 ha in those deferred for 84 days, 0.46 ha in paddocks deferred for 105 days and 0.38 ha in those deferred for 126 days) in order to ensure minimum forage production of $2,250 \mathrm{~kg}$ DM per deferral period and forage allowance of $8 \%$.

Table 2. Chemical analysis of the soil in the experimental area.

\begin{tabular}{|c|c|c|c|c|c|c|c|c|c|c|c|c|}
\hline \multirow{2}{*}{$\begin{array}{c}\mathbf{p H} \\
\left(\mathrm{H}_{2} \mathrm{O}\right)\end{array}$} & \multirow{2}{*}{$\begin{array}{c}\mathbf{m g} / \mathbf{d m}^{3} \\
P\end{array}$} & \multicolumn{8}{|c|}{$\mathrm{cmol}_{\mathrm{c}} / \mathbf{d m}^{3}$ soil } & \multicolumn{2}{|c|}{$\%$} & \multirow{2}{*}{$\begin{array}{l}\mathbf{g} / \mathbf{d m}^{3} \\
\text { M.O. }\end{array}$} \\
\hline & & $\mathrm{K}^{+}$ & $\mathrm{Ca}^{2+}$ & $\mathrm{Mg}^{2+}$ & $\mathrm{Al}^{3+}$ & $\mathrm{H}^{+}$ & S.B. & $\mathrm{t}$ & $\mathrm{T}$ & $\mathrm{V}$ & $\mathrm{m}$ & \\
\hline 5.8 & 3 & 0.36 & 3.3 & 2.2 & 0.1 & 1.9 & 5.8 & 5.9 & 7.7 & 75 & 2 & 19.6 \\
\hline
\end{tabular}

Source: Elaboration of the authors.

Uniform grazing was made $10 \mathrm{~cm}$ from the ground before sealing the area. Sealing of experimental units began on March 23 $3^{\text {rd }}, 2012$, with areas subjected to the longest deferral period (126 days) and, at every 21 days, the other areas were fenced: 105 days (13/04/2012), 84 days $(04 / 05 / 2012)$ and 63 days of deferral (25/05/2012). On July $27^{\text {th }}, 2012$, the last experimental unit was fenced.

Forage evaluations were performed at the beginning and end of the grazing period. The first occurred at the end of the sealing period, on $27 / 07 / 2012$, before the animals entered the paddocks. The second, 70 days after. Forage samples were taken to estimate the dry matter production of each paddock and consequently, deferral period, as well as for chemical analysis.

To estimate the dry matter (DM) availability of each experimental unit, initially, a visual evaluation of the area was made by assigning scores, using the height and the amount of forage as parameters, score 1 was assigned to the forage with $20-30 \mathrm{~cm}$ height; with $30-45 \mathrm{~cm}$ height, score 2; and forage with height above $45 \mathrm{~cm}$, score 3, altering these values according to variation in sward height.
Subsequently, with the aid of a square of area equivalent to $0.49 \mathrm{~m}^{2}(0.70 \times 0.70 \mathrm{~m})$, randomly thrown 40 times in each paddock, 40 visual estimates were obtained to determine the proportion of the respective scores. After the estimation of visual scores, using the same square, three forage samples were taken per score, by cutting all forage contained within the square at a height of $10 \mathrm{~cm}$ from the ground (with pruning shears), storing all the material per score in plastic bags previously identified. Then, we determined the average weight of forage per square and per score. Forage collected in each score was homogenized and then formed a composite sample of forage of the 3 scores at the same proportions of the respective scores, and from this, two representative portions were separated, a composite for estimating DM availability of each paddock and one for separations into leaf blade and stem, according to the methodology described by McMeniman (1997). Of the material collected in each paddock, representative samples were taken to determine the nutritional value of pastures in the different deferral periods. The composite sample was weighed and packed in paper bag and dried in a forced ventilation oven at $60^{\circ} \mathrm{C}$ for 72 hours, weighed, ground in a Wiley mill and stored in plastic 
containers previously identified for subsequent chemical analysis. The availability of the structural components and the proportion of leaf blade are presented in Table 3.
The animals were distributed according to forage allowance ( $8 \%$ body weight); in agreement with Thiago (1999), this allowance is ideal for the dry season and the availability of forage during the initial period, with adjustments along the evaluation period, at 28 days and at 56 days.

Table 3. Availability of total dry matter, in $\mathrm{kg} \mathrm{ha}^{-1}$, leaf blade and stem, and proportion of leaf blade in pastures of Brachiaria decumbens $\mathrm{cv}$. Basilisk, subjected to four deferral periods.

\begin{tabular}{cccccc}
\hline & & \multicolumn{4}{c}{ Deferral period } \\
\cline { 3 - 5 } & Grazing & $\mathbf{6 3}$ days & $\mathbf{8 4}$ days & $\mathbf{1 0 5}$ days & $\mathbf{1 2 6}$ days \\
\hline \multirow{2}{*}{ ATDM } & Initial & 1.464 & 2.692 & 2.574 & 2.448 \\
& Final & 895 & 1.169 & 1.698 & 1.281 \\
\multirow{2}{*}{ ALBDM } & Initial & 699 & 1.204 & 1.212 & 1.123 \\
& Final & 127 & 170 & 290 & 120 \\
\multirow{2}{*}{ ASDM } & Initial & 551 & 1.216 & 1.146 & 1.016 \\
& Final & 365 & 505 & 791 & 667 \\
& Initial & 48 & 45 & 47 & 46 \\
& Final & 15 & 14 & 17 & 10 \\
\hline
\end{tabular}

ATDM = availability of total dry matter; ALBDM = availability of leaf blade dry matter; ASDM = availability of stem dry matter. Source: Elaboration of the authors.

The feeding behavior was evaluated for two crossbreed Holstein: Zebu heifers per paddock, totaling 24 animals with an average age of 6 months and average body weight of $157.06 \pm$ $23.78 \mathrm{~kg}$. Additionally, the animals were identified for morphological characteristics, with numbered plastic earrings and fluorescent collars for easier identification and management during evaluations. The evaluation was conducted in two stages: one on the $12^{\text {nd }}$ day and the other on the $40^{\text {th }}$ day of the experiment, corresponding to the days $09 / 08 / 2012$ and 06/09/2012.

Heifers received multiple supplementation at a ratio of $0.3 \% \mathrm{BW}$, previously balanced to contain nutrients to meet the requirements for average daily gain of $0.5 \mathrm{~kg}$, according to the NRC (1996). The supplement was composed of ground corn (52.1\%); soybean meal (37.2\%); mineral salt (4.7\%) and urea
+ ammonium sulfate $9: 1(6 \%)$, with the following chemical composition: dry matter $(88.6 \%)$; crude protein $(40.8 \%)$; neutral detergent fiber corrected for ash and protein $(28.3 \%)$; acid detergent fiber (17.3\%); ether extract (2.1\%); mineral matter (7.7\%) and non-fiber carbohydrates $(21 \%)$, percentage of dry matter. Supplementation was provided once a day at 8:00 am in collective plastic trough, not covered, with $90 \times 60 \times 30 \mathrm{~cm}$. All animals had free access to water, shade and multiple supplement.

To estimate the voluntary intake of forage, we used the internal marker indigestible NDF (iNDF) (CASALI, 2009). The apparent digestibility of nutrients (AD) was determined by the methodology described by Silva and Leão (1979). The intake and digestibility of dry matter and nutrients are presented in Table 4. 
Table 4. Intake, in $\mathrm{kg} \mathrm{day}^{-1}$, and digestibility, in percentage, of dry matter and nutrients by crossbred Holstein: Zebu heifers on pastures of Brachiaria decumbens $\mathrm{cv}$. Basilisk subjected to four deferral periods.

\begin{tabular}{lcccc}
\hline & \multicolumn{4}{c}{ Deferral period } \\
\cline { 2 - 5 } & $\mathbf{6 3}$ days & $\mathbf{8 4}$ days & $\mathbf{1 0 5}$ days & $\mathbf{1 2 6}$ days \\
\hline TDM Intake & 5.1 & 4.7 & 4.3 & 4.2 \\
TDN Intake & 3.0 & 2.5 & 2.2 & 2.1 \\
DM digestibility & 60.2 & 56.2 & 53.6 & 54.5 \\
TDN & 56.3 & 52.1 & 50.0 & 49.6 \\
\hline
\end{tabular}

$\mathrm{TDM}=$ total dry matter (pasture + supplement); TDN = total digestible nutrients; DM = dry matter.

The studied behavioral data were the time spent in the activities of grazing, rumination, idle and in the trough. Behavioral activities were considered mutually exclusive, as defined by Pardo et al. (2003). The animals were visually observed every 5 minutes (MEZZALIRA et al., 2011) for 24 hours by an observer at each paddock. Observers were previously trained and strategically positioned so as not to affect animal behavior. To facilitate observation, each observer had binoculars on hand. For the time spent on each activity, the evaluator used digital watches and during the night, the observer used flashlights to aid in data collection.

The total feeding time (TFT) and the total chewing time (TCT) were determined by the following equations:

$\mathrm{TFT}=$ grazing time + feeding time at the trough;

$\mathrm{TCT}=$ grazing time + rumination time + feeding time at the trough.

The number of cud chewings of the same animals evaluated for feeding behavior was recorded by a trained observer as well as the time spent in ruminating each ruminal bolus, for each animal, conducting observations of four ruminal boluses in three different periods of the day (from $09 \mathrm{~h} 00$ to $12 \mathrm{~h} 00$; from $15 \mathrm{~h} 00$ to $18 \mathrm{~h} 00$ and from $19 \mathrm{~h} 00$ to 21h00), according to Bürger et al. (2000). The number of daily boluses was obtained by dividing the total rumination time by the average time spent ruminating each bolus, as described above.

The discretization of the time series was made directly in the data spreadsheet, with the counting of discrete periods of grazing, rumination, idle and in the trough. The average duration of each discrete period was obtained by dividing the daily times for each activity by the number of discrete periods of the same activity, as described by Silva et al. (2006).

The variables gMS and NDF/meal were obtained by dividing the average individual intake of each fraction by the daily number of feeding periods within 24 hours.

The feeding efficiency was calculated according to the methodology described by Bürger et al. (2000), in which dry matter intake efficiency (DMIE) is equal to the pasture dry matter intake (DMI) (in $\mathrm{kg}$ ) by the feeding time (in hours). The neutral detergent fiber intake efficiency (NDFIE) is equal to the pasture neutral detergent fiber intake (NDFI) (in kg) by the feeding time (in hours). The total digestible nutrient intake efficiency (TDNIE) is equal to the intake of total digestible nutrients in the diet (in $\mathrm{kg}$ ) divided by the feeding time (in hours). Dry matter rumination efficiency (DMRE) is equal to the pasture dry matter intake (DMI) (in $\mathrm{kg}$ ) by the rumination time (in hours) and neutral detergent fiber rumination efficiency (NDFRE) is equal to the intake of pasture neutral fiber detergent (in $\mathrm{kg}$ ) by the rumination time (in hours).

Based on the methodology adapted from Palhano et al. (2006), grazing tests were conducted in a single session to evaluate the number of feeding stations, in steps per minute and per station, and bite rate per minute per station. Two heifers (Holstein/ Zebu), per experimental unit, following a solid and 
liquid fasting for six hours, early in the morning, were transferred to the experimental area. Then, the animals were monitored in the grazing session lasting 45 minutes by four previously trained evaluators, two for each animal, by counting the number of selected feeding stations, the number of steps taken by the animals, the number of bites and the feeding time. A feeding station was defined as a hypothetical semicircle available in front of the animal that can be achieved without movement of the forelegs. The steps were counted using as a criterion the movement of the forelegs, while the feeding time was computed as the effective period of forage capture, excluding periods of displacement and demand, so that when the animal moved for more than six seconds, without forage intake, the stopwatches were turned off.

Results were tested by analysis of variance and regression analysis using the System for Statistics and and Genetic Analysis - SAEG (RIBEIRO JÚNIOR, 2001). The criteria used to select the model were the coefficient of determination calculated as the ratio of the sum of squares of the regression and the sum of squares of treatments and the significance of the regression coefficients, through F-test.

\section{Results and Discussion}

The total time spent per day by animals in activities of grazing, idle, rumination and in the trough was not different $(p>0.05)$ between the deferral periods. Mean values of time spent on each activity were 566.6 minutes (09h26) in grazing, 422.3 minutes (07h02) in idleness, 427.0 minutes (07h06) in rumination and 24.1 minutes feeding in the trough (Table 5). Because the adjustment of foragae allowance was $8 \%$, it is justified the similarity of the results found in this study.

Table 5. Total time spent daily in activities of grazing, idle, rumination and in the trough by heifers on pastures of Brachiaria decumbens $\mathrm{cv}$. Basilisk subjected to four deferral periods.

\begin{tabular}{|c|c|c|c|c|c|c|c|}
\hline \multirow{2}{*}{$\begin{array}{c}\text { Activity } \\
\text { (min/day) }\end{array}$} & \multicolumn{4}{|c|}{ Deferral period } & \multirow{2}{*}{ CV $(\%)^{1}$} & \multirow{2}{*}{$\mathbf{P}^{2}$} & \multirow{2}{*}{$\mathbf{R} \mathbf{E}^{3}$} \\
\hline & 63 days & 84 days & 105 days & 126 days & & & \\
\hline Grazing & 511.7 & 582.9 & 585.4 & 586.2 & 19.4 & 0.28 & $\hat{Y}=566.6$ \\
\hline Idle & 488.7 & 410.4 & 399.2 & 390.8 & 23.9 & 0.08 & $\hat{\mathrm{Y}}=422.3$ \\
\hline Rumination & 415 & 422.5 & 433.7 & 436.7 & 16.6 & 0.87 & $\hat{\mathrm{Y}}=427.0$ \\
\hline Trough & 25 & 23.7 & 21.2 & 26.2 & 28.5 & 0.33 & $\hat{\mathrm{Y}}=24.1$ \\
\hline
\end{tabular}

${ }^{1}$ Coefficient of variation, in percentage. ${ }^{2}$ Probability of error. ${ }^{3}$ Regression equation.

Baggio et al. (2008) claimed that the behavioral variables, such as grazing time, number of meals and meal time, are directly correlated to the abundance of forage, sward structure and forage intake by the animal. The value found in this study for grazing time, $09 \mathrm{~h} 26$, is in the range described by Euclides et al. (2000), in general, the grazing time ranges from 7 to 12 hours per day.

Conducting research and understanding the behavior of animals is very important for decisions on the property aimed at obtaining better farming conditions and consequently better results in production. In general, behavioral activities (grazing, idle, rumination) follow the same pattern among animals. With time ranges considered optimal for each, the differences occur due to differences in each specific situation, as a result of intrinsic characteristics and relationships between plant, animal and environment.

According to Pompeu et al. (2009), the use of protein supplementation for grazing ruminants can influence production and behavior of the animal by changing the intake of forage, promoting changes in the behavior habits of the animal (grazing, 
rumination and other activities) and influencing the performance. Here in this study, the supplementation was identical, both in composition and in the percentage provided, and its supply did not affect the evaluated variables, but may have allowed the increase in pasture consumption, favoring the higher average performance of animals. In accordance to Moore (1980), the animals receiving energy-protein supplements also tend to reduce forage intake due to the replacement or combined effects, spending less time in grazing activity (POMPEU et al., 2009). Which has probably not occurred in this study with the supply of $0.3 \%$ body weight supplement.

Zanine et al. (2006b) worked with animals of different categories on Brachiaria decumbens pasture and observed idleness values of 5.5; 5.9 and 6.0 hours, with no difference between calves, heifers and cows, respectively. The value found in this study was higher than those found by these authors.

The ruminating activity in adult animals occupies about 8 hours per day, varying between 4 and 9 hours (VAN SOEST, 1994; ZANINE et al., 2006a). The results of this study are within the variation range.

Deferral periods had quadratic effect $(p<0.05)$ on the number of periods in the grazing activity, which was observed in the intermediate deferral period, with minimal point of 9.34 periods, reached after 95 sealing days (Table 6), possibly because the animals have found, at that period, the preferred forage, not needing to visit other patches.

Table 6. Number of periods in activities of grazing, idle, rumination and in the trough by heifers on pastures of Brachiaria decumbens $\mathrm{cv}$. Basilisk subjected to four deferral periods.

\begin{tabular}{|c|c|c|c|c|c|c|c|}
\hline \multirow{2}{*}{$\begin{array}{c}\text { Activity } \\
\text { (min/day) }\end{array}$} & \multicolumn{4}{|c|}{ Deferral period } & \multirow[b]{2}{*}{$\mathrm{CV}(\%)^{1}$} & \multirow[b]{2}{*}{$\mathbf{P}^{2}$} & \multirow[b]{2}{*}{$\mathbf{R} \mathbf{E}^{3}-\mathbf{r}^{2,4}$} \\
\hline & $\begin{array}{c}63 \\
\text { days }\end{array}$ & $\begin{array}{c}84 \\
\text { days }\end{array}$ & $\begin{array}{c}105 \\
\text { days }\end{array}$ & $\begin{array}{c}126 \\
\text { days }\end{array}$ & & & \\
\hline $\mathrm{N}^{\circ}$ grazing periods & 12.0 & 9.3 & 9.8 & 11.7 & 22.5 & 0.02 & $\begin{array}{c}\hat{\mathrm{Y}}= \\
32.35-0.485 \mathrm{x}+0.0026 \mathrm{x}^{2} \\
\mathrm{r}^{2}=0.97\end{array}$ \\
\hline $\mathrm{N}^{\circ}$ idle periods & 27.2 & 21.9 & 19.7 & 20.8 & 26.6 & 0.02 & $\begin{array}{c}\hat{\mathrm{Y}}=32.08-0.102 \mathrm{x} \\
\mathrm{r}^{2}=0.69\end{array}$ \\
\hline $\mathrm{N}^{\circ}$ rumination periods & 18.4 & 15.2 & 14.0 & 16.9 & 25.4 & 0.06 & $\hat{\mathrm{Y}}=16.1$ \\
\hline $\mathrm{N}^{\circ}$ periods in the trough & 1.9 & 1.6 & 1.58 & 1.9 & 61.9 & 0.77 & $\hat{\mathrm{Y}}=1.7$ \\
\hline
\end{tabular}

${ }^{1}$ Coefficient of variation, in percentage. ${ }^{2}$ Probability of error. ${ }^{3}$ Regression equation. ${ }^{4}$ Coefficient of determination.

The higher availability of total dry matter at the beginning of grazing (Table 3) may have contributed to the longer permanence of animals in the intermediate deferral sites, with consequent fewer grazing periods, because pastures satisfied the requirements, without the need for rapid change of stations, but with similar total grazing time between deferral periods.

The number of idle periods presented a decreasing linear effect $(p<0.05)$, so that, for each deferral day, there was a decrease of 0.102 in the number of idle periods (Table 6). This may have been caused by the effect of the number of grazing periods and the individual characteristics of animals.

During the 70 days in which animals remained in the paddocks, the number of feeding stations, the time spent in the stations and the number of feeding stations per minute were not significantly different ( $>$ > 0.05) between the evaluated deferral times (Table 7).

The amount of dry matter and green leaves available interfere with the permanence of animals 
in the feeding stations. With the forage allowance adjusted at the entry of the heifers, these results may have been caused by the similarity of the selected and consumed pasture, because, between different deferral periods, the leaf percentage was similar (Table 3).
The mean value of 20.1 seconds recorded for the time spent in the feeding stations (Table 7) was higher than the values found by Pizzuti et al. (2012), with a mean value of 8.5 seconds. The only supply of Brachiaria decumbens and characteristics of pastures observed herein may have been the reason of the mean value found in this study.

Table 7. Number of feeding stations, time spent in feeding stations, in minutes, number of feeding stations per minute, time per feeding station, in seconds, number of bites, number of bites per minute, number of bites per feeding station, number of steps and number of steps per feeding station of crossbred Holstein: Zebu heifers on pastures of Brachiaria decumbens $\mathrm{cv}$. Basilisk subjected to four deferral periods.

\begin{tabular}{|c|c|c|c|c|c|c|c|}
\hline \multirow{3}{*}{$\begin{array}{l}\text { Item } \\
\text { FS }\end{array}$} & \multicolumn{4}{|c|}{ Deferral period } & \multirow{2}{*}{\multicolumn{2}{|c|}{$\mathrm{CV}(\%)^{1} \mathrm{P}^{2}$}} & \multirow[b]{2}{*}{$\mathbf{R E}^{3} \mathbf{r}^{2,4}$} \\
\hline & \multirow{2}{*}{$\begin{array}{c}\begin{array}{c}63 \\
\text { days }\end{array} \\
80.5 \\
\end{array}$} & \multirow{2}{*}{$\begin{array}{c}\begin{array}{c}84 \\
\text { days }\end{array} \\
108.4\end{array}$} & \multirow{2}{*}{$\begin{array}{c}\begin{array}{c}105 \\
\text { days }\end{array} \\
98.7\end{array}$} & \multirow{2}{*}{\begin{tabular}{r|}
$\begin{array}{c}126 \\
\text { days }\end{array}$ \\
137.9
\end{tabular}} & & & \\
\hline & & & & & 59.3 & 0.34 & $\hat{\mathrm{Y}}=106.4$ \\
\hline Min $\mathrm{FS}^{-1}$ & 30.7 & 35.6 & 35.8 & 36.4 & 20.4 & 0.35 & $\hat{\mathrm{Y}}=34.6$ \\
\hline FS $\min ^{-1}$ & 2.48 & 2.9 & 3.0 & 3.7 & 63.0 & 0.61 & $\hat{\mathrm{Y}}=3.0$ \\
\hline Sec FS ${ }^{-1}$ & 22.9 & 19.7 & 21.8 & 15.8 & 61.0 & 0.63 & $\hat{\mathrm{Y}}=20.1$ \\
\hline Bit & 798.2 & 1271.1 & 867.9 & 899.7 & 37.2 & 0.04 & $\hat{Y}=-1091.1+46.78 x-0.25 x^{2} r^{2}=0.36$ \\
\hline Bit $\min ^{-1}$ & 25.2 & 36.5 & 23.8 & 25.0 & 32.2 & 0.02 & $\hat{Y}=-14.9+1.03 x-0.0058 x^{2} r^{2}=0.33$ \\
\hline Bit FS ${ }^{-1}$ & 12.6 & 17.2 & 12.4 & 8.6 & 82.4 & 0.43 & $\hat{\mathrm{Y}}=12.7$ \\
\hline S & 352.4 & 361.3 & 316.8 & 303.7 & 45.55 & 0.8 & $\hat{Y}=333.6$ \\
\hline $\mathrm{S} \min ^{-1}$ & 13.5 & 10.8 & 9.0 & 8.4 & 67.5 & 0.46 & $\hat{\mathrm{Y}}=10.4$ \\
\hline $\mathrm{S} \mathrm{FS}^{-1}$ & 8.2 & 4.3 & 5.2 & 2.2 & 125.8 & 0.30 & $\hat{\mathrm{Y}}=5.0$ \\
\hline
\end{tabular}

${ }^{1}$ Coefficient of variation, in percentage. ${ }^{2}$ Probability of error. ${ }^{3}$ Regression equation. ${ }^{4}$ Coefficient of determination. FS $=$ number of feeding stations; Min FS ${ }^{-1}=$ time spent in feeding stations, in minutes; FS min $^{-1}=$ number of feeding stations per minute; Seg FS ${ }^{-1}$ $=$ time per feeding station, in seconds; Bit $=$ number of bites; Bit $\min ^{-1}=$ number of bites per minute; $\mathrm{Bit}_{\mathrm{FS}}{ }^{-1}=$ number of bites per

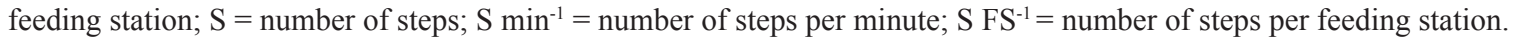

When the availability of forage and structural characteristics are not limiting, there is a longer permanence time, in other words, it is observed a reduced number of feeding stations in the same time interval, as well as a higher number of steps between stations, as the animal takes a higher bite mass in the last previous season, which allows the animal to walk between stations for longer while chewing. In turn, in situations of low supply of forage, the animals tend to show short and rectilinear displacements and the number of steps between stations is low, reflecting the lower bite mass taken in the last bite in the previous station (TEIXEIRA et al., 2011).
Deferral periods had a quadratic effect on the number of bites and number of bites per minute, with maximum point of 1,098 bites and 31 bites per minute, achieved at 93 and 88 deferral days, respectively (Table 7). It is worth noting that, in this period, the animals demonstrated the lowest numbers of grazing periods (Table 6), coinciding with the results obtained with 84 and 105 deferral days, with minimal point at 95 days. To compensate for the consumption requirements, animals needed to take more bites, given the lack of difference in the time spent per station $(\mathrm{p}>0.05)$. 
The number of bites per station was not different ( $>0.05$ ) between the periods evaluated, averaging 12.7 bites per station (Table 7). In this study, the results of intake were similar, which may have been caused by the availability of forage and canopy structure. The number of bites per station was higher than those reported by Teixeira et al. (2011) in Brachiaria decumbens pastures deferred for 95 days.

The number of steps taken during the evaluation period, and the number of steps per minute and per feeding station were not statistically different $(p>$ 0.05 ) between deferral periods, with mean values of $333.59,10.43$ and 4.95 , respectively (Table 7).
The mean value of 5.0 steps per feeding station was higher than the result of 2.6 found by Teixeira et al. (2011). As in this research, the quality and supply of forage were similar between the deferral periods, it is possible that these variables show no differences in the number of steps per station.

Further, feed efficiency in relation to intake of dry matter, neutral detergent fiber corrected for ash and protein and total digestible nutrients per hour, as well as efficiencies in rumination of dry matter and neutral detergent fiber corrected for ash and protein were linearly affected decreasing $(p<0.05)$ by different deferral periods (Table 8 ).

Table 8. Feed efficiency in crossbred Holstein: Zebu heifers on pastures of Brachiaria decumbens cv. Basilisk subjected to four deferral periods.

\begin{tabular}{|c|c|c|c|c|c|c|c|}
\hline \multirow{2}{*}{ Item } & \multicolumn{4}{|c|}{ Deferral period } & \multirow{2}{*}{$\begin{array}{l}C V \\
(\%)^{1}\end{array}$} & \multirow{2}{*}{$\mathbf{P}^{2}$} & \multirow{2}{*}{$\mathbf{R E}^{3} \mathbf{r}^{2,4}$} \\
\hline & 63 days & 84 days & 105 days & 126 days & & & \\
\hline DMIE $^{-1}$ & 591.6 & 494.5 & 430.7 & 418.4 & 20.4 & $3.10^{-4}$ & $\hat{\mathrm{Y}}=746.28-2.778 \mathrm{x} \mathrm{r}^{2}=0.90$ \\
\hline NDFapIE $h^{-1}$ & 362.6 & 303.8 & 272.9 & 263.1 & 20.3 & 0.001 & $\hat{\mathrm{Y}}=448.83-1.57 \mathrm{x} \mathrm{r}^{2}=0.90$ \\
\hline TDNIE $^{-1}$ & 346.2 & 268.0 & 225.1 & 216.0 & 20.7 & 1.3. $10^{-6}$ & $\hat{\mathrm{Y}}=458.97-2.065 \mathrm{x} \mathrm{r}^{2}=0.89$ \\
\hline $\mathrm{DMRE}^{-1}$ & 765.7 & 693.8 & 600.4 & 587.2 & 18.1 & 0.002 & $\hat{\mathrm{Y}}=944.86-2.995 \mathrm{x} \mathrm{r}^{2}=0.93$ \\
\hline RENDFap $h^{-1}$ & 469.3 & 426.3 & 380.4 & 369.2 & 18.0 & 0.007 & $\hat{\mathrm{Y}}=567.1-1.65 \mathrm{x} \mathrm{r}^{2}=0.95$ \\
\hline
\end{tabular}

${ }^{1}$ Coefficient of variation, in percentage. ${ }^{2}$ Probability of error. ${ }^{3}$ Regression equation. ${ }^{4}$ Coefficient of determination. DMIE $h^{-1}=$ dry matter intake efficiency; NDFapIE $h^{-1}=$ neutral detergent fiber corrected for ash and protein intake efficiency; TDNIE $h^{-1}=$ total digestible nutrients intake efficiency; DMRE $\mathrm{h}^{-1}=$ dry matter rumination efficiency; RENDFap $\mathrm{h}^{-1}=$ rumination efficiency of neutral detergent fiber corrected for ash and protein

While the supply of forage, the availability of leaf dry matter and intake were similar between the deferral periods, it is supposed the same trend in the results of efficiency. Our findings found could be related to individual behavioral differences of animals.

The grazing and idle periods, the number of bites, the number of bites per minute and the feed efficiency were influenced by different deferral periods of pastures, under the conditions of this study.

\section{Acknowledgements}

To the Federal Institute of Education, Science and Technology Bahian - Campus Itapetinga, Brazil.

\section{References}

ANUÁRIO DA PECUÁRIA BRASILEIRA ANUALPEC. 2013. 20 $0^{\text {td }}$ ed. São Paulo, SP, BR: Instituto FNP. 289p.

BAGGiO, C.; CARVAlHO, P. C. F.; SILVA, J. L. S.; ROCHA, L. M.; BREMM, C.; SANTOS, D. T.; MONTEIRO, A. L. G. Padrão de uso do tempo por novilhos em pastagem consorciada de azevém anual e aveia-preta. Revista Brasileira de Zootecnia, Viçosa, MG, v. 37, n. 11, p. 1912-1918, 2008.

BÜRGER, P. J.; PEREIRA, J. C.; QUEIROS, A. C.; SILVA, J. F. C.; VALADARES FILHO, S. C.; CECON, P. R.; CASALI, A. D. P. Comportamento ingestivo em bezerros holandeses alimentados com dietas contendo diferentes níveis de concentrado. Revista Brasileira de Zootecnia, Viçosa, MG, v. 29, n. 1, p. 236-242, 2000. 
CASALI, A. O.; DETMANN, E.; VALADARES FILHO, S. D. C.; PEREIRA, J. C.; CUNHA, M.; DETMANN, K. S. C.; PAULINO, M. F. Estimation of fibrous compounds contents in ruminant feeds with bags made from different textiles. Revista Brasileira de Zootecnia, Viçosa, MG, v. 38, n. 1, p. 130-138, 2009.

EUClidES, V. P. B.; CARDOSO, E. G.; MACEDO, M. C. M.; OLIVEIRA, M. P. Consumo voluntário de Brachiaria decumbens cv. Basilisk e Brachiaria brizantha cv. Marandu sob pastejo. Revista Brasileira de Zootecnia, Viçosa, MG, v. 29, n. 6, p. 2200-2208, 2000.

MCMENIMAN, N. P. Methods of estimating intake of grazing animals. In: REUNIÃO ANUAL DA SOCIEDADE BRASILEIRA DE ZOOTECNIA, SIMPÓSIO SOBRE TÓPICOS ESPECIAIS EM ZOOTECNIA, 34., 1997, Juiz de Fora. Anais... Juiz de Fora: [s,n.], 1997. p. 131-168.

MEZZALIRA, J. C.; CARVALHO, P. C. F.; FONSECA, L.; BREMM, C.; REFFATTI, M. V.; POLI, C. H. E. C.; TRINDADE, J. K. Aspectos metodológicos do comportamento ingestivo de bovinos em pastejo. Revista Brasileira de Zootecnia, Viçosa, MG, v. 40, n. 5, p. 11141120, 2011.

MOORE, J. E. Forage Crops. In: HOVELAND, C. S. (Ed.). Crop quality, storage and utilization. american society of agronomy. Madison, Wisconsin: Crop Science Society of America, 1980. p. 61-91.

NRC. Nutrient Requirements of Beef Cattle. 7th ed. Nat. Acad. Press, Washington, DC. 1996. 242 p.

NUTRIENT REQUIREMENTS OF BEEF CATTLE NRC. $7^{\text {th }}$ ed. Washington: Nat. Acad. Press, 1996. 242 p.

PALHANO, A. L.; CARVALHO, P. C. F.; DITTRICH, J. R.; MORAES, A.; SILVA, S. C.; MONTEIRO, A. L. G. Características do processo de ingestão de forragem por novilhas holandesas em pastagens de capim-mombaça. Revista Brasileira de Zootecnia, Viçosa, MG, v. 36, n. 4, p. 1014-1021, 2007.

PALHANO, A. L.; CARVALHO, P. C. F.; DITTRICH, J. R.; MORAES, A.; SILVA, S. C.; MONTEIRO, A. L. Padrões de deslocamento e procura por forragem de novilhas leiteiras em pastagem de capim-mombaça. Revista Brasileira de Zootecnia, Viçosa, MG, v. 35, n. 6, p. 2253-2259, 2006.

PARDO, R. M. P.; FISCHER, V.; BALBINOTTI, M.; MORENO, C. B.; FERREIRA, E. X.; VINHAS, R. I.; MONKS, P. L. Comportamento ingestivo diurno de novilhos em pastejo a níveis crescentes de suplementação energética. Revista Brasileira de Zootecnia, Viçosa, MG, v. 32, n. 6, p. 1408-1418, 2003.
PIZZUTI, L. A. D.; ALVES FILHO, D. C.; BRONDANI, I. L.; PACHECO, P. S.; FREITAS, L. S.; SEGABINAZZI, L. R.; CALLEGARO, A. M.; TEIXEIRA, O. S. Behavior pattern of beef heifers supplemented with different energy sources on oat and ryegrass pasture. Revista Brasileira de Zootecnia, Viçosa, MG, v. 41, n. 8, p. 1921-1927, 2012.

POMPEU, R. C. F. F.; ROGÉRIO, M. C. P.; CÂNDIDO, M. J. D. N.; NEIVA, J. N. M.; GUERRA, J. L. L.; GONÇALVES, J. S. Comportamento de ovinos em capim-tanzâniasob lotação rotativa com quatro níveis de suplementação concentrada. Revista Brasileira de Zootecnia, Viçosa, MG, v. 38, n. 2, p. 374-383, 2009.

RIBEIRO JÚNIOR, J. I. Análises estatísticas no SAEE: sistema para análises estatísticas. Viçosa, MG: UFV, 2001.

SILVA, J. F. C.; LEÃO, M. I. Fundamentos de nutrição dos ruminantes. Piracicaba: Livro Ceres, 1979. 380 p.

SILVA, R. R.; SILVA, F. F.; PRADO, I. N.; CARVALHO, G. G. P.; FRANCO, I. L.; ALMEIDA, V. S.; CARDOSO, C. P.; RIBEIRO, M. H. S. Comportamento ingestivo de bovinos. Aspectos metodológicos. Archivos de Zootecnia, Córdoba, v. 55, n. 211, p. 293-296, 2006.

TEIXEIRA, F. A.; BONOMO, P.; PIRES, A. J. V.; SILVA, F. F.; MARQUES, J. A.; SANTANA JÚNIOR, H. A. Padrões de deslocamento e permanência de bovinos em pastos de Brachiaria decumbens diferidos sob quatro estratégias de adubação. Revista Brasileira Zootecnia, Viçosa, MG, v. 40, n. 7, p. 1489-1496, 2011.

THIAGO, L. R. L. Suplementação de bovinos em pastejo: aspectos práticos para o seu uso na mantença ou ganho de peso. In: ENCONTRO DE TECNOLOGIAS PARA A PECUÁRIA DE CORTE, 11., 1999, Campo Grande. Palestra... Campo Grande [s.n], 1999.

VAN SOEST, P. J. Nutritional ecology of the ruminant. $2^{\text {th }}$ ed. Ithaca: Cornell University, 1994. $476 \mathrm{p}$.

ZANINE, A. M.; SANTOS, E. M.; FERREIRA, D. J. Tempo de pastejo, ócio, ruminação e taxas de bocadas de bovinos em pastagens de diferentes estruturas morfológicas. Revista Eletrônica de Veterinária, Garça, v. 7, n. 1, p. 1-9, 2006 a.

ZANINE, A. M.; SANTOS, E. M.; PARENTE, H. N.; FERREIRA, D. J.; CECON, P. R. Comportamento ingestivo de bezerros em pastos de Brachiaria brizantha e Brachiaria decumbens. Ciência Rural, Santa Maria, v. 36 , n. 5, p. 825-832, 2006 b. 